\title{
INVESTIGATION OF HEAT-HUMIDITY TRANSFER IN HIGH-POROUS GAS-FILLED POLYMERS TO CALCULATE ITS HEAT CONDUCTIVITY
}

\author{
Vladimir V. Gur'ev' ${ }^{1}$,Vadim I. Nikitin ${ }^{2}$, Valeriy A. Kofanov ${ }^{3}$ \\ ${ }^{1}$ Federal Centre for Regulation, Standardization and Technical Assessment in Construction, Moscow, RUSSIA \\ ${ }^{2}$ Pope John Paul II State School of Higher Education, Biała Podlaska, POLAND \\ ${ }^{3}$ Brest State Technical University, Brest, BELARUS
}

\begin{abstract}
A method for calculating the effective thermal conductivity of moisture-containing highly porous foamed polymers is proposed. In this method a non-additive scheme for taking into account the effect of steam diffusion on heat transfer is used. The sequential binary systems (interstitial substance from a liquid and a vaporgas mixture, as well as a polymer skeleton and an intra-porous substance) are described by models of structures with interpenetrating components and isolated inclusions. The conditions for the transition from one model of structure to another are defined and there is not necessity to define empirical coefficients. A geometric model of wet foamed polymer has been developed, that allows us to find a way to determine the value of the boundary moisture content of pores or wetting angle at which the transition from partial wetting of the surface of the pores with liquid to full wetting and vice versa occurs. A mathematical description of the process of heat transfer in the model structure of a wet foamed polymer has been made, taking into account the diffusion of water vapor in the pore space.
\end{abstract}

Keywords: effective heat conductivity, interpenetrating components, high-porous gas-filled polymers, polyurethane foam, vapor diffusion, wetting angle

\section{ИССЛЕДОВАНИЕ ТЕПЛОВЛАГООБМЕНА В ВЫСОКОПОРИСТЫХ ГАЗОНАПОЛНЕННЫХ ПОЛИМЕРАХ ПРИМЕНИТЕЛЬНО К РАСЧЕТУ ИХ ТЕПЛОПРОВОДНОСТИ}

\author{
В.В. Гурьев ${ }^{1}$, В.И. Никитин ${ }^{2}$, В.А. Кофанов ${ }^{3}$ \\ ${ }^{1}$ Федеральный центр нормирования, стандартизации и технической оценки соответствия \\ в строительстве Минстроя России, г. Москва, РОССИЯ \\ ${ }^{2}$ Государственная высшая школа имени Папы Римского Иоанна Павла II, г. Бяла Подляска, ПОЛЬША \\ ${ }^{3}$ Брестский государственный технический университет, г. Брест, РЕСПУБЛИКА БЕЛАРУСЬ
}

Аннотация: В данной работе предлагается метод расчета эффективной теплопроводности влагосодержащих высокопористых пенопластов, в котором используется неаддитивная схема учета влияния диффузии пара на перенос тепла. Приведена разработанная геометрическая модель влажного пенопласта, позволяющая найти способ определения значения граничного влагосодержания пор или краевого угла смачивания, при которых происходит переход от частичного смачивания поверхности пор жидкостью к полному смачиванию и наоборот. Расчетами показано, что такой переход сопровождается скачкообразным изменением теплопроводности пенопластов. Выполнено математическое описание процесса переноса тепла в модельной структуре влажного пенопласта с учетом диффузии водяного пара в поровом пространстве. Расчетным путем установлено заметное влияние влагосодержания и средней температуры пенопласта на его эффективную теплопроводность при аддитивной и неаддитивной схемам учета диффузионной составляющей теплопроводности.

Ключевые слова: тепловлагообмен, высокопористые газонаполненные полимеры, расчет теплопроводности, диффузия пара, угол смачивания 


\section{INTRODUCTION}

Rigid polymeric foams (foamed polymers) are widely used in construction and other industries as an effective thermal insulation of buildings and structures. A generalized characteristic of the complex process of heat conduction in foamed polymers is the effective thermal conductivity coefficient $\lambda$, used to determine the heat-shielding properties of thermal insulation structures.

It is obvious that the thermal conductivity coefficient of foamed polymers depends on the thermal conductivity of the dense polymer skeleton and the interporous substance, which in moisturecontaining materials consists of a vapor-gas mixture and water. When determining the thermal conductivity of such an interporous substance, it is necessary to take into account the influence of a diffusive flow of steam-like moisture moving in the direction of heat flow and accompanied by phase transformations of moisture in the pores (evaporation in the warm zone and condensation in the cold) $[1,2,3,4]$. At the same time, due to condensation of the diffusing vapor, the thermal conductivity of wet materials and, above all, of highly porous foamed polymers, may significantly increase.

Evaluation of the influence of steam diffusion on heat transfer is currently performed using additive and non-additive schemes. Thus, in [4], the effective thermal conductivity of a wet foamed polymer consists of heat conduction due to condensation of diffusing steam, which is determined using the relation that is similar to the Fourier law for heat flux, recommended for use in the temperature range from 20 to $90^{\circ} \mathrm{C}$ and containing empirical coefficients, and thermal conductivity of the wet material, determined by the Krischer formula, also containing the empirical coefficient. The presence of empirical coefficients imposes certain restrictions on the use of these dependencies in the calculations.

The authors of [3] estimate the effect of vapor diffusion on heat transfer by using a non-additive calculation scheme, simulating a wetted material by a structure with interpenetrating components.
An analysis of a three-component system containing a polymer skeleton, liquid moisture and a vapor-gas mixture was carried out using the method of sequential reduction of a multicomponent system to a binary one. First, the effective thermal conductivity of the pore space containing the liquid and the vapor - gas mixture (binary system with interpenetrating components) was determined, and then the effective thermal conductivity of the wet material consisting of the polymer skeleton and the inter-porous substance was determined. The thermal conductivity of the vapor - gas mixture was represented as the sum of the thermal conductivity of dry gas and the thermal conductivity of steam, caused by diffusive transfer of steam in the pore space.

In highly porous foamed polymers, liquid moisture wets the surface of the pores partially (more often) or completely (less often). In the first case, the pore space model should be represented in the form of a binary system with isolated inclusions, and in the second case, in the form of a binary system with interpenetrating components. When changing the moisture content of the pores or the wetting angle, it is possible transition from one binary system to another. In this case we need to know the value of the boundary (critical) moisture content or wetting angle. However, the described calculation schemes do not take into account this important feature.

\section{STRUCTURE'S MODEL OF WET FOAMED POLYMER AND ITS CALCULATIONAL RELATIONSHIPS}

When developing the model of wet foamed plastic, the real cellular structure of the polymer skeleton is replaced by an adequate model with an ordered rod structure consisting of identical elementary cells of a cubic form. This form of the unit cell is fairly reasonable and the simplest. In order to assess the character of the distribution of liquid moisture in this cell, it is necessary to take into account the moisture content of the material $\psi$ and the wetting angle $\Theta$ formed at the boundary of the solid, liquid and gas. From the analysis 
of the results of numerous experimental studies that carried out in laboratory and natural conditions and partially presented in $[4,5,6]$, it follows that at constant contact with the environment for which humidity and temperature are changing, the volume moisture content of polyurethane and phenolic foamed polymers can reach $\psi=0.06-0.07 \mathrm{~m}^{3} / \mathrm{m}^{3}$. To determine the wetting angle $\Theta$, it is used the method of a large drop of liquid (3-4 $\left.\mathrm{cm}^{3}\right)$ wetting the flat horizontal surface of the polymer [7]. After five independent measurements of the wetting angle with water of a polyurethane surface at a temperature of $20^{\circ} \mathrm{C}$, it turned out that the measured random variable is characterized by an arithmetic average value $\bar{\theta}$ $=56^{\circ}$ and a sample standard deviation $\mathrm{s}=3.2^{\circ}$.

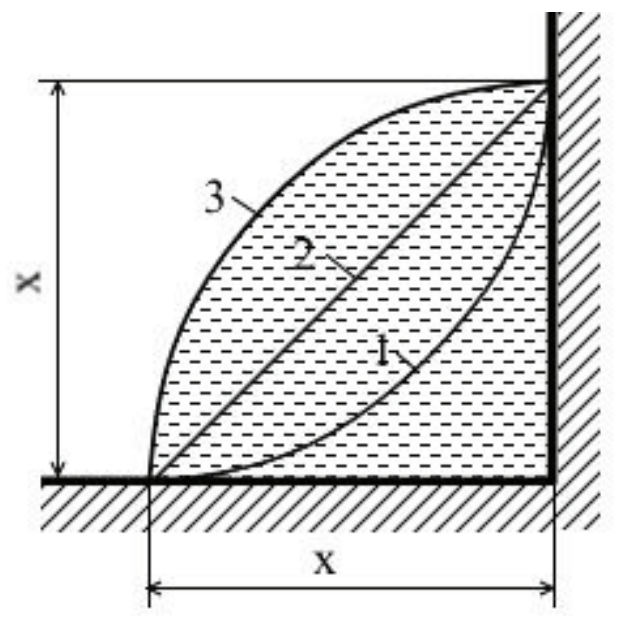

$$
1-\theta=0^{\circ} ; 2-\theta=45^{\circ} ; 3-\theta=90^{\circ}
$$

Figure 1. View of the liquid surface in the dihedral angle at various wetting angles.

Figure 1 shows the nature of the distribution of a very small amount of liquid in the form of a strip of constant cross section in a two-sided angle formed by two mutually perpendicular halfplanes at different wetting angles. If we start from the average cell sizes of polyurethane foams given in [8], it can be assumed that the size $\mathrm{x}$ in Figure 1 does not exceed $200 \mu \mathrm{m}$. In this case, under normal conditions, gravity will not be able to distort the surface of the liquid (water) shown in Figure 1, since the values of the gravitational forces are no more than $0.5 \%$ of the values of the surface tension forces. Then it is not difficult to imagine the nature of the distribution of fluid in the unit cell. As an example, Figure 2 shows the eighth part of a unit cell containing an isolated fluid inclusion at a wetting angle $\Theta=45^{\circ}$.

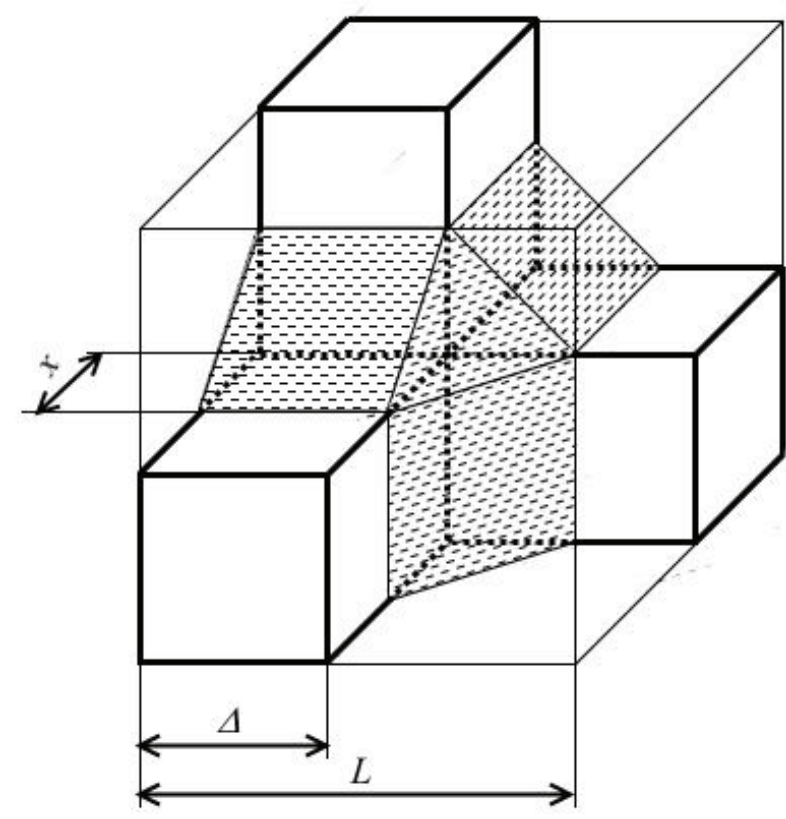

Figure 2. The nature of the distribution of isolated inclusion of liquid in the unit cell at a wetting angle $\theta=45^{\circ}$.

With an increase in moisture content, the size $\mathrm{x}$ (Figure 2) increases and at

$$
x=L-\Delta
$$

isolated fluid inclusions merge and porous space should be considered as a binary system with inter-penetrating components. Thus, when calculating the thermal conductivity of the pore space, it is necessary to know its boundary moisture content, at which the binary system with isolated inclusions transforms to the system with interpenetrating components and vice versa.

The volume moisture content of pores $\psi_{\mathrm{p}}$ is related to the volume of a liquid $\mathrm{V}_{\mathrm{w}}$ and pores $\mathrm{V}_{\mathrm{p}}$ by a ratio

$$
\psi_{p}=V_{w} / V_{p}
$$

or to the volume moisture content of a material $\psi$ and its porosity $m$ by ratio 


$$
\psi_{p}=\psi / m
$$

From Figure 2 it follows that

$$
V_{w}=3 \cdot x^{2} \cdot \Delta / 2+x^{6} / 6
$$

Pore volume

$$
V_{p}=(L-\Delta)^{3}+3 \cdot \Delta \cdot(L-\Delta)^{2}
$$

Accepting $x=L-\Delta$, after simple transformations, we obtain the volumetric boundary moisture content of pores at a wetting angle $\Theta=45^{\circ}$

$$
\psi_{p}^{\prime}=\frac{1+8 \cdot c}{6 \cdot(1+2 \cdot c)} ; c=\Delta / L
$$

Analogically for wetting angle value $\theta=90^{\circ}$ we obtain

$$
\psi_{p}^{\prime}=\frac{\pi \cdot(1+3.5 \cdot c)}{6 \cdot(1+2 \cdot c)} .
$$

For wetting angle value $\theta=0^{\circ}$ the unknown value of moisture content is determined by formula

$$
\psi_{p}^{\prime}=\frac{(4-\pi) \cdot(1+14 \cdot c)}{20 \cdot(1+2 \cdot c)} .
$$

Using formulas (1), (2) and (3), it can be determined the relationship for pore moisture content $\psi_{p}^{\prime}$ from wetting angle $\theta$ for different values of the rods' relative sizes $c=\Delta / L$ of elementary cell. This relationship is illustrated in Figure 3. The relative size of the rods is calculated using the ratio [9]:

$$
c=0.5+\sin \left[\frac{\arcsin \left(2 \cdot m_{i}-1\right)}{3}\right],
$$

where $m_{i}$ is concentration of the $i$-th component $(i=1,2)$, for which the value $c$ should be determined.

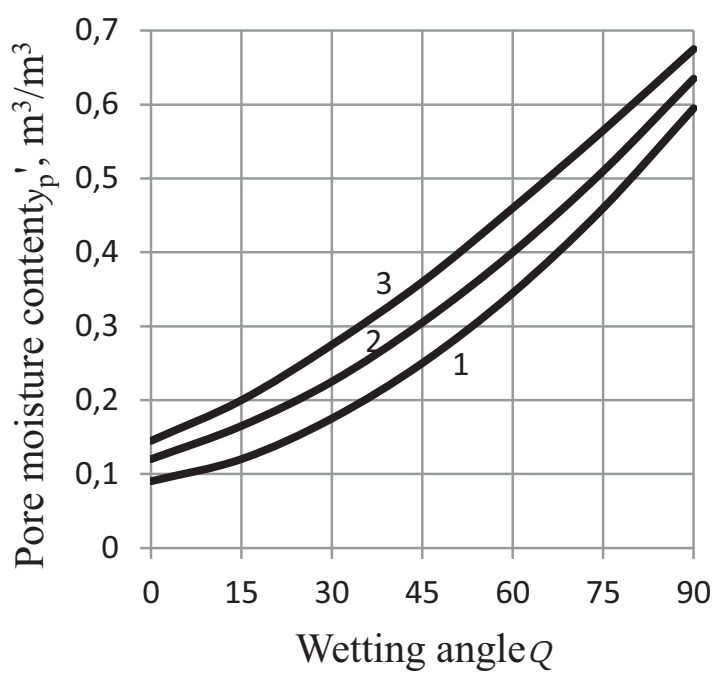

$$
1-c=0.1 ; 2-c=0.2 ; 3-c=0.3
$$

Figure 3. The relationship between boundary moisture content of the pores $\psi_{p}^{\prime}$ and the wetting angle $\theta$ at different relative sizes of the rods of the unit cell $c$.

In order to determine effective heat conductivity for binary system with known components' concentrations $m_{1}, m_{2}$ and its heat conductivities $\lambda_{1}$, $\lambda_{2}$, let us apply relationships, turned out on the basis generalized conductivity theory [3].

For the structure with interpenetrating components, the dependence obtained by G.N. Dulnev in 1965 is used.

$$
\begin{aligned}
& \qquad \begin{array}{l}
\lambda=\lambda_{1} \cdot\left[c^{2}+v \cdot(1-c)^{2}+\right. \\
+2 \cdot v \cdot c \cdot(1-c) \cdot(v \cdot c+1-c)^{-1}, \\
\text { where } \\
\quad v=\lambda_{2} / \lambda_{1} .
\end{array}
\end{aligned}
$$

The components of this structure are geometrically equal and in the calculations it does not matter which of the two components is taken as the first.

For the structure with closed inclusions, the following dependence is chosen:

$$
\lambda=\lambda_{1} \cdot \frac{1+(v-1) \cdot\left(1-m_{2}^{2 / 3}\right) \cdot m_{2}^{1 / 3}}{v-(v-1) \cdot m_{2}^{1 / 3}},
$$


where $m_{2}$ is volumetric inclusion's concentration, $v=\lambda_{2} / \lambda_{1}$.

In this case, the components of the structure are geometrically unequal and the continuous component is always the first with the concentration $m_{1}$.

When calculating the thermal conductivity of wet foamed polymer, let us consider the vapor-air mixture as one of the continuous components, since during the operation of the thermal insulation structures there is a diffusion replacement of gas, formed in the pores of the foamed plastics during its manufacture, by air and water vapor. According to $[1,2,3]$, the thermal conductivity of the vapor - air mixture $\lambda_{v a}$ equals to the sum of the thermal conductivities of air $\lambda_{a}$ and vapor $\lambda_{v}$. Thermal conductivity of steam $\lambda_{v}$, caused by diffusive vapor transfer in the pore space, can be determined by the formula [3]

$$
\lambda_{v}=\frac{D}{\mu} \cdot \frac{M}{R \cdot T} \cdot \frac{P_{v a}}{P_{v a}-P_{v}} \cdot \frac{d P_{v}}{d T} \cdot q_{t},
$$

where $D$ is coefficient of water vapor diffusion in still air, $\mathrm{m}^{2} / \mathrm{s} ; \mu$ is coefficient of resistance to vapor diffusion through the pore space; $M$ is molecular weight of steam, $\mathrm{kg} / \mathrm{mole} ; R$ is universal gas constant, $\mathrm{J} /($ mole $\cdot \mathrm{K}) ; T$ is vapor temperature, $\mathrm{K}$; $P_{v a}$ is total vapor and air pressure, $\mathrm{Pa} ; P_{v}$ is vapor partial pressure, $\mathrm{Pa} ; q_{t}$ is specific heat of vaporization at temperature $T, \mathrm{~J} / \mathrm{kg}$.

In determining the coefficient $D$, it is widely used dependence, which was justified by R. Schirmer [10] in 1938

$$
\begin{aligned}
D=\frac{2.305 \cdot 10^{-5} \cdot P_{o}}{P_{v a}} \cdot\left(\frac{T}{273}\right)^{1.81} & , \\
P_{o} & =101323 \mathrm{~Pa} .
\end{aligned}
$$

The experimental value of the coefficient $\mu$ is determined from the ratio

$$
\mu=D / \delta_{v},
$$

where $\delta_{v}$ is vapor permeability coefficient of the porous medium, $\mathrm{m}^{2} / \mathrm{s}$.

Experiments can be avoided if it is possible to choose the most suitable formula for the described material from a large number of the proposed formulas. A preliminary analysis showed that, for wet foamed polymers with an open-cell structure, for the concentration of the vapor-air mixture

$$
m-\psi \geq 0.93,
$$

it can be suggested a simple formula [4]

$$
\mu=\frac{1}{0.57 \cdot(m-\psi)}, \psi \leq \psi_{p} \cdot m
$$

For values

$$
m-\psi<0.93
$$

it can be applied dependence [11]

$$
\mu=\tau^{2} /(m-\psi),
$$

where $\tau$ is the tortuosity coefficient, which according to [9] is proposed to be found from the relationship:

$$
\tau=(m-\psi) / c^{2} .
$$

Here the parameter $\mathrm{c}$ is determined by the formula (4) for

$$
m_{1}=m-\psi
$$

Substituting the relation (12) in (11) we finally obtain

$$
\mu=(m-\psi) / c^{4}
$$

It seems to be expedient to begin the calculation of the diffusion component of thermal conductivity $\lambda_{v}$ of foamed polymers when a moisture content is not less than the maximum gyroscopic one 
$\psi_{h}$ and constant at a given temperature and pressure of the saturated vapor $p_{v h}$.

\section{SCHEME OF A CALCULATION}

Let us illustrate the recommended calculation scheme using the example of calculating the effective thermal conductivity of a foamed polymer specimen with a porosity of $m=0.93$, a density of $\rho=80 \mathrm{~kg} / \mathrm{m} 3$, moisture content $\psi=0.06$ $\mathrm{m}^{3} / \mathrm{m}^{3}$ that is close to the largest operating value, average temperature $t=20^{\circ} \mathrm{C}$ and wetting angle $\Theta=60^{\circ}$.

At the beginning, using the formula (7), we calculate the diffusion component of thermal conductivity at $\lambda_{v}, \mathrm{~T}=293 \mathrm{~K}, P_{v a}=10^{5} \mathrm{~Pa}$. According to reference data we find $M=0.018 \mathrm{~kg} / \mathrm{mol}, R$ $=8.3144 \mathrm{~J} /(\mathrm{mol} \cdot \mathrm{K}), P_{v}=P_{v h}=0.02338 \cdot 10^{5} \mathrm{~Pa}$,

$$
\frac{d P_{v h}}{d T}=148 \mathrm{~Pa} / \mathrm{K}(\text { for } d T=1 \mathrm{~K}),
$$

$q_{t}=2.38 \cdot 10^{6} \mathrm{~J} / \mathrm{kg}$. According to the formula (8), we determine the diffusion coefficient of vapor in the air $\mathrm{D}=2.65 \cdot 10^{-5} \mathrm{~m}^{2} / \mathrm{s}$. To calculate the coefficient $\mu$, we use formula (13) with the volume concentration of the vapor-air mixture and the parameter $\mathrm{c}=0.7743$, found by formula (4) for $m_{1}=m=0.87$. Then we have $\mu=2.42$.

As a result, we obtain $\lambda_{v}=0.03 \mathrm{~W} /(\mathrm{m} \cdot \mathrm{K})$ and, taking into account the thermal conductivity of dry air, $\lambda_{v}=0.0257 \mathrm{~W} /(\mathrm{m} \cdot \mathrm{K})$, the thermal conductivity of the vapor-air mixture is

$$
\lambda_{v a}=\lambda_{v}+\lambda_{a}=0.0557 \mathrm{~W} /(\mathrm{m} \cdot \mathrm{K}) .
$$

The volume moisture content of the pore space is equal to

$$
\psi_{p}=\psi / m=0.06 / 0.93=0.0645 \mathrm{~m}^{3} / \mathrm{m}^{3} .
$$

At a wetting angle $\Theta=60^{\circ}$ and the parameter $\mathrm{c}$ $=0.1614$, calculated by the formula (4) with a polymer volume concentration of $m_{1}=0.07$, using Figure 3, the boundary moisture content of pores $\psi_{p}^{\prime}=0.38 \mathrm{~m}^{3} / \mathrm{m}^{3}$ was found, which exceeds the actual $\psi_{p}=0.0645 \mathrm{~m}^{3} / \mathrm{m}^{3}$ almost 6 times. In this case, the pore space containing the vapor-air mixture and water is considered as a binary system (structure) with isolated inclusions. The first component of this system is a vapor-air mixture with a volume concentration of $m_{1}=$ 0.9355 and thermal conductivity

$$
\lambda_{1}=\lambda_{v a}=0.0557 \mathrm{~W} /(\mathrm{m} \cdot \mathrm{K}),
$$

and the second one is water with a volume concentration of $m_{2}=0.0645\left(m_{1}+m_{2}=1\right)$ and thermal conductivity

$$
\lambda_{2}=\lambda_{w}=0.596 \mathrm{~W} /(\mathrm{m} \cdot \mathrm{K}) .
$$

Now, using the formula (6) with the ratio

$$
v=\lambda_{2} / \lambda_{1}=0.596 / 0.0557=10.7,
$$

we calculate the effective thermal conductivity of the pore substance

$$
\lambda_{12}=0.0608 \mathrm{~W} /(\mathrm{m} \cdot \mathrm{K})
$$

At the final stage of calculation, using formula (5) for a structure with equal interpenetrating components, we determine the effective thermal conductivity $\lambda$ of a wet foamed polymer. As the first component, we consider the inter-porous substance, for which we have

$$
m_{1}=m=0.93, \lambda_{1}=\lambda_{12}=0.0608 \mathrm{~W} /(\mathrm{m} \cdot \mathrm{K})
$$

and the parameter $c=0.8386$, obtained by formula (4). The second component is a polymer skeleton characterized by $\mathrm{m}_{2}=0.07$ and $\lambda_{2}=0.25$ $\mathrm{W} /(\mathrm{m} \cdot \mathrm{K})$. Then we have a relationship

$$
v=\lambda_{2} / \lambda_{1}=0.25 / 0.0608=4.1118 \text {. }
$$

For the obtained values of parameters $c$ and $v$, we calculate the effective thermal conductivity of 
the wet foamed polymer $\lambda=0.068 \mathrm{~W} /(\mathrm{m} \cdot \mathrm{K})$ using formula (5).

For comparison, according to the considered scheme, a calculation is performed in which, when determining the thermal conductivity of the pore substance $\lambda_{12}$, the heat transfer due to condensation of the diffusing vapor $\lambda_{V}$ is not taken into account. In this case, the value of the effective thermal conductivity of the wet foamed polymer is $\lambda^{\prime}=0.0354 \mathrm{~W} /(\mathrm{m} \cdot \mathrm{K})$, that is almost two times less than the result of the previous calculation. If we use the additive calculation scheme and determine the effective thermal conductivity of the wet foamed polymer as a sum, we get the result

$$
\lambda=0.0354+0.03=0.0654 \mathrm{~W} /(\mathrm{m} \cdot \mathrm{K}),
$$

which is only $3.8 \%$ less than the result calculated by the non-additive scheme. Let us note that, when implementing another additive calculation scheme using the formulas recommended in [4] and containing empirical coefficients, the effective thermal conductivity is obtained equal to $\lambda=$ $0.0745 \mathrm{~W} /(\mathrm{m} \cdot \mathrm{K})$, which is $9.6 \%$ higher than the value calculated from proposed non-additive calculation scheme. Exactly the same result is given by the proposed calculation scheme using the value of the vapor diffusion coefficient $\mu=$ 2.016, which is obtained using formula (10).

\section{NUMERICAL EXPERIMENT AND ITS RESULTS}

A numerical experiment is carried out to assess the effect of moisture content $\psi$ and the average temperature $t$ of the considered foam plastic on its thermal conductivity $\lambda$. To this end, the presented example of calculating $\lambda$, which takes into account different approaches to estimating $\lambda$, was repeated for other values of moisture content for the range from 0.01 to 0.3 . According to the results of repeated calculations, graphs are constructed reflecting various dependencies of $\lambda$ on $\psi$, that are shown in figure 4 together with exper- imental data taken from [4]. Comparing dependence 1 in figure 4 with the other dependences, it follows that the diffusion component of thermal conductivity $\lambda_{v}$ for various ways of taking it into account makes a significant contribution to the effective thermal conductivity $\lambda$ of wet foamed polymer. Using formula (10) to determine the vapor diffusion resistance coefficient $\mu$ instead the formula (13) we obtain noticeable differences (qualitative and quantitative) in calculating the effective thermal conductivity $\lambda$ (dependences 3 and 4). Comparison of dependences 2 and 3 shows that the additive and non-additive schemes for taking the diffusion component $\lambda_{v}$ into account when determining the effective thermal conductivity of the foamed polymer gives similar results within the maximum operating moisture content of $\psi \leq 0.07$. In this case, the results of the non-additive calculation exceed the results of the additive calculation no more than $4 \%$. With an increase in the moisture content of the material to $\psi=0.3$, this difference increases to $15 \%$.

From figure 4 it can be seen that for the same material with moisture holding $\psi>0.2$, the experimental data of some authors (triangles) exceed the experimental data of other authors (circles) approximately two times, and the calculated curve 3 obtained using the recommended calculation schemes, well predicted by experimental data, indicated by circles. It was also experimentally established [3] that the thermal conductivity of the same material with the same moisture content may differ several times. First of all, this can be explained by the fact that at the same moisture content, but different wetting angles, the moisture can wet the surface of the pores fully or partially.

For the considered foamed plastic $(\mathrm{m}=0.93$ and $\psi=0.3$ ), we have a moisture content of pores

$$
\psi_{p}=\psi / m=0.323
$$

which corresponds to the boundary wetting angle $\theta^{\prime}=52^{\circ}$ (figure 3 ). 


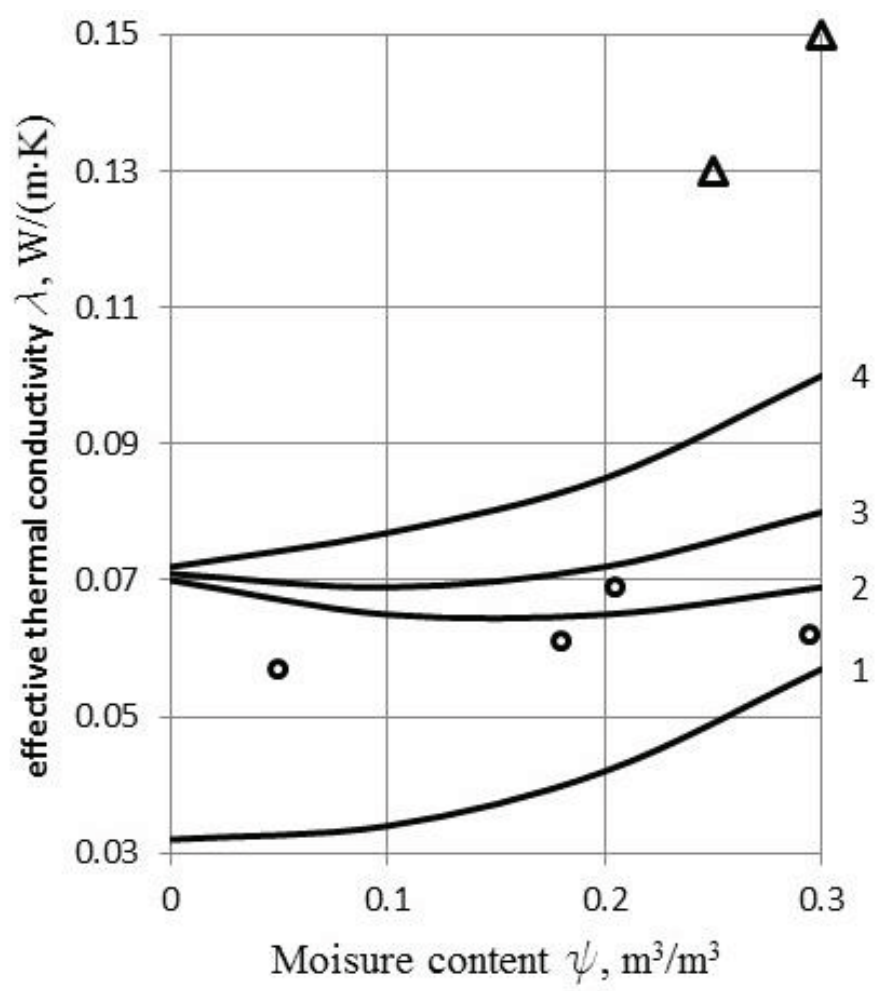

$\circ, \Delta$ are experimental data obtained by various authors

Figure 4. Dependence of effective thermal conductivity $\lambda$ on moisture content $\psi$ for foamed plastic with porosity $m=0.93$ at a temperature of $20^{\circ} \mathrm{C}$ and wetting angle $\theta=60^{\circ}$ and various ways of accounting for thermal conductivity of water vapor $\lambda_{v}$ due to its diffusion:

1 - excluding; 2 - additive; 3, 4 - non-additive with different formulas for calculating the coefficient of resistance to vapor diffusion.

At wetting angles $\Theta<52^{\circ}$ and moisture content $\psi=0.3$, the surface of the pores is completely wetted with water and the pore space can be represented as a binary system with interpenetrating components, the thermal conductivity of which is determined by formula (5). In this case, the value of the effective thermal conductivity of a wet foamed polymer is

$$
\lambda=0.136 \mathrm{~W} /(\mathrm{m} \cdot \mathrm{K}),
$$

that exceeds the value of thermal conductivity calculated for the same foam with partial water wetting of the pore surface $\left(\Theta>52^{\circ}\right), 1.71$ times. It accurately predicts the experimental value

$$
\lambda=0.15 \mathrm{~W} /(\mathrm{m} \cdot \mathrm{K})
$$

presented in Figure 4. For another moisture content $\psi=0.25\left(\psi_{\mathrm{p}}=0.269\right)$ and a wetting angle $\Theta$ $<45^{\circ}$, the calculated value

$$
\lambda=0.121 \mathrm{~W} /(\mathrm{m} \cdot \mathrm{K})
$$

is close to another experimental value

$$
\lambda=0.13 \mathrm{~W} /(\mathrm{m} \cdot \mathrm{K}) \text { (Figure } 4) .
$$

Thus, with the correct quantitative assessment of the wetting of the surface of the pores with a liquid (partially or completely), determined using the parameters $\psi$ and $\Theta$, the proposed method for calculating the thermal conductivity of foamed polymers $\lambda$ can satisfactorily predict experimental data.

The calculations confirm the well-known effect of increasing the heat conductivity of a wet foamed polymers with an increase in its average temperature. 


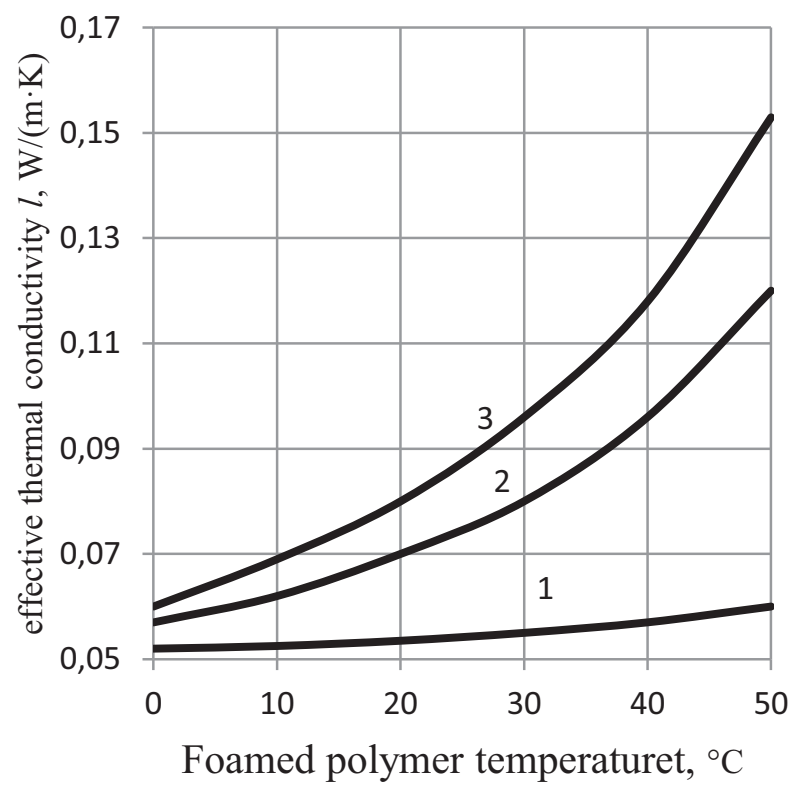

Figure 5. Dependence of the effective thermal conductivity $\lambda$ on the average temperature of the foamed polymer with a porosity of $m=0.93$ with a moisture content of $\psi=0.3$ and a wetting angle of $\theta=60^{\circ}$ and various ways of accounting for the thermal conductivity of water vapor $\lambda_{v}$ due to its diffusion

1 - excluding; 2 - additive; 3 - non-additive.

At the same time, within the limits of the operational moisture content of the material $\psi \leq 0.07$, the difference between the values of thermal conductivity calculated by additive and non-additive calculation schemes does not exceed $4 \%$. With an increase in the moisture content of the material to $\psi=0.3$, this difference increases, that is shown by dependences 2 and 3 in figure 5 .

\section{CONCLUSIONS}

A geometric model of wet foamed polymer has been developed, that allows us to find a way to determine the value of the boundary moisture content of pores or wetting angle at which the transition from partial wetting of the surface of the pores with liquid to full wetting and vice versa occurs. Calculations have shown that such a transition is accompanied by an abrupt change in the thermal conductivity of foamed polymers. A mathematical description has been made for the process of heat transfer in the model structure of a wet foamed polymer, taking into account the diffusion of water vapor in the pore space. By calculation, a significant influence of the moisture content and average temperature of the foamed polymer on its effective thermal conductivity with additive and non-additive schemes for accounting for the diffusion component of thermal conductivity has been established. Comparison of the calculation results with experimental data revealed its rather exact coincidence.

\section{REFERENCES}

1. Lykov A.V. Teplomassoobmen [Heat and Mass Transfer]. Moscow, 1971, 560 pages (in Russian).

2. Missenard A. Conductivit. Thermique des Solides, Liquides, Gaz et de Leurs Mélanges, Paris, Éditions Eyrolles, 1985, 340 pages.

3. Dul'nev G.N., Novikov V.V. Protsessy Perenosa V Neodnorodnykh Sredakh 
[Transport Processes in Inhomogeneous Media]. Leningrad, 1991, 248 pages (in Russian).

4. Gur'ev V.V., Zholudov V.S., Petrov-Denisov V.G. Teplovaya Izolyatsiya v Promyshlennosti. Teoriya i Raschet. [Thermal Insulation in Industry. Theory and Calculation]. Moscow, 2003, 416 pages (in Russian).

5. Thermal Insulation Materials Made of Rigid Polyurethane Foam (PUR/PIR): Report No. 1 (October) / BING: Federation of European Rigid Polyurethane Foam Associations. Brussels, 2006, 33 pages.

6. Petrov-Denisov V.G., Maslennikov L.A. Protsessy Teplo- i Vlagoobmena v Promyshlennoy Izolyatsii [Processes of Heat and Moisture Exchange in Industrial Insulation]. Moscow, 1983, 193 pages (in Russian).

7. Gur'ev V.V., Nikitin V.I., Golubova G.A. Sposob Opredeleniya Kraevogo Ugla Smachivaniya Polimernykh Kompozitsiy [Method for Determining the Contact Angle of Wetting of Polymer Compositions]. Patent. RU 2025710 /. Published 30.12.1994 (in Russian).

8. Collishaw P.G., Evans J.R.G. An Assessment of Expressions for the Apparent Thermal Conductivity of Cellular Materials. // Journal of Materials Science, 1994, Vol. 29, pp. 486-498.

9. Nikitsin V.I., Backiel-Brzozowska B. Determination of Capillary Tortuosity Coefficient in Calculations of Moisture Transfer in Building Materials // International Journal of Heat and Mass Transfer, 2013, Vol. 56, pp. 30-34.

10. Scheffler G.A., Plagge R. A Whole Range Hygric Material Model: Modelling Liquid and Vapour Transport Properties in Porous Media. // International Journal of Heat and Mass Transfer, 2010, Vol. 53, pp. 286-296.

11. Epstein N. On Tortuosity and the Tortuosity Factor in Flow and Diffusion Through Porous Media. // Chemical Engineering Science, 1989, Vol. 44, No 3, pp. 777-779.

\section{СПИСОК ЛИТЕРАТУРЫ}

1. Лыков А.В. Тепломассообмен. - М.: Энергия, 1971. - 560 с.

2. Missenard A. Conductivit. Thermique des Solides, Liquides, Gaz et de Leurs Mélanges, Paris, Éditions Eyrolles, 1985, 340 pages.

3. Дульнев Г.Н., Новиков В.В. Процессы переноса в неоднородных средах. - Л.: Энергоатомиздат. Ленинградское отделение, 1991. - 248 с.

4. Гурьев В.В., Жолудов В.С., Петров-Денисов В.Г. Тепловая изоляция в промышленности. Теория и расчет. - М.: Стройиздат, 2003. - 416 c.

5. Thermal Insulation Materials Made of Rigid Polyurethane Foam (PUR/PIR): Report No. 1 (October) / BING: Federation of European Rigid Polyurethane Foam Associations. Brussels, 2006, 33 pages.

6. Петров-Денисов В.Г., Масленников Л.А. Процессы тепло- и влагообмена в промышленной изоляции. - М.: Энергоатомиздат, 1983. - $193 \mathrm{c.}$

7. Способ определения краевого угла смачивания полимерных композиций : пат. RU 2025710 / В.В. Гурьев, В.И. Никитин, Г.А. Голубова. Опубл. 30.12.1994.

8. Collishaw P.G., Evans J.R.G. An Assessment of Expressions for the Apparent Thermal Conductivity of Cellular Materials. // Journal of Materials Science, 1994, Vol. 29, pp. 486-498.

9. Nikitsin V.I., Backiel-Brzozowska B. Determination of Capillary Tortuosity Coefficient in Calculations of Moisture Transfer in Building Materials // International Journal of Heat and Mass Transfer, 2013, Vol. 56, pp. 30-34.

10. Scheffler G.A., Plagge R. A Whole Range Hygric Material Model: Modelling Liquid and Vapour Transport Properties in Porous Media. // International Journal of Heat and Mass Transfer, 2010, Vol. 53, pp. 286-296. 
11. Epstein N. On Tortuosity and the Tortuosity Factor in Flow and Diffusion Through Porous Media. // Chemical Engineering Science, 1989, Vol. 44, No 3, pp. 777-779.

Vladimir V. Gur'ev, Advisor of the Russian Academy of Architecture and Construction Sciences, Professor, Dr.Sc.; Federal Centre for Regulation, Standardization and Technical Assessment in Construction; Floor 2, Building 3, Str. 1, Orlikov Pereulok, Moscow, 107139, Russia; phone: +7 (495) 133-01-57; e-mail: info@faufcc.ru.

Vadim I. Nikitin, Professor, Dr.Sc., Pope John Paul II State School of Higher Education; Rzeczpospolita Polska, 21500, woj. Lubelskie, Biała Podlaska, ul. Sidorska, 95/97; phone: +48 8334499 00; fax: +48 8334445 90, E-mail:psw@pswbp.pl.

Valeriy A. Kofanov, Associate Professor, Ph.D., Brest State Technical University; 267, Moskovskaya Str., Brest, 224017, Belarus; phones: + 375162 42-33-93;

+ 375 162 42-40-84; fax: + 375 162 42-21-27;

E-mail: canc@bstu.by.

Гурьев Владимир Владимирович, советник РААСН, профессор, доктор технических наук; Россия, 107139, Москва, Орликов пер., 3, стр. 1; тел. +7(495) 133-01-57; E-mail: info@faufcc.ru.

Никитин Вадим Иванович, профессор, доктор технических наук, Государственная высшая школа имени Папы Римско-го Иоанна Павла II; Rzeczpospolita Polska, 21-500, woj. Lubelskie, Biała Podlaska, ul. Sidorska, 95/97; тел. +48 8334499 00;

факс +48 8334445 90, e-mail: psw@pswbp.pl.

Кофанов Валерий Анатольевич, доцент, кандидат технических наук, Брестский государственный технический университет; ул. Московская 267, 224017, Брест, Республика Беларусь; тел.: +375 162 32-17-32;

факс: +375 162 32-17-55; e-mail: canc@bstu.by. 